\title{
Suitability of human capital for better results of supply chain management: Lessons from national government department
}

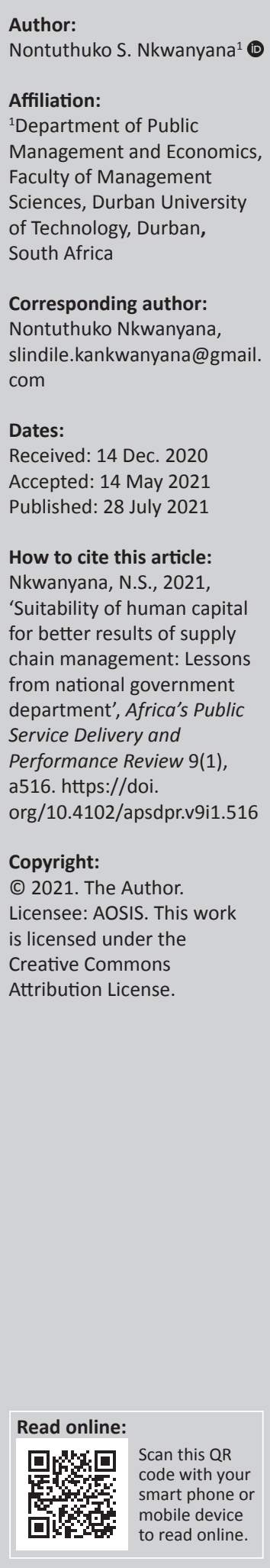

Background: The establishment of supply chain management (SCM) throughout the public service promised better outcomes due to improved processes and governance. However, since inception, SCM has been criticised for inefficiency in achieving its mandate. As a system, it has been labelled as 'yet again' another failed government initiative, because communities at large believe that this system too is associated with a number of flaws.

Aim: The aim of this study was to examine the role that human capital plays in SCM in fulfilling end customer services in the public sector.

Setting: The study focused on the national government department, South Africa.

Method: To achieve the above objective, a quantitative research methodology was used to ascertain the adequacy of human capital dimensions as a factor of SCM in ensuring good customer service in the public sector.

Results: Findings indicate that there is: (1) a notable shortage of human resources; (2) scanty knowledge on the processes employed within SCM; (3) a lack of suitable training; (4) performance that is somewhat not in order and (5) the results of SCM, although with some desire, were also found not to be in good standing.

Conclusion: This study revealed that reasonable care has not been taken to make a favourable environment, through human capital, to achieve better results of SCM in the public sector, and when human capital is not set accordingly, performance of SCM is likely to be negatively impacted.

Keywords: supply chain management; system; processes; procurement; human capital.

\section{Introduction}

A growing body of knowledge, both academic and in the media, suggests that supply chain management (SCM) has not been successful in achieving the mandate for which it was designed and implemented. As a system, it appears as 'yet again' another disastrous initiative. In all sectors, namely both private and public entities in South Africa (SA), an indication suggests that this system is greatly challenged. In the public sector, instances such as those of gross non-adherence to set laws resulting in unauthorised, fruitless, wasteful and irregular expenditure (Auditor General of South Africa 2019; Stemele 2009:68), fronting, fraud and bid ricking (Ngobeni 2011:2) continue to rise. Moreover, payment of exorbitant prices for goods and services continues to re cur (De Lange 2011). Until recently, exorbitant charges remain a challenge. This could be identified in the report of 'Forensic investigations into alleged irregular procurement of Personal Protective Equipment and blankets (2020)' where blankets were procured at an excessive price of between R350.00 and R559.00. On the other hand, De Lange 2011; Kshetri and Voas (2019:1) reported SCM in the private sector as being a source of cyber breach, whilst Setino (2018:144-145) reported a mix of SCM non-compliance by state-owned enterprises (SOEs). Meanwhile, the world has adopted SCM as means for business survival (Jiang 2020:960), as it was labelled as an ingredient for business success. The above therefore reflect, 'all is not well within SCM'. Flaws similar to the above were reported in SA in the past. Authors such as Migiro and Ambe (2008:235) reported non-adherence to policies, order splitting and collusion between suppliers and officials. 
Irregularities were also noted by Bizana, Naude and Ambe (2015:680), who indicated that there was cover-quoting; misrepresentation and awarding of work to companies whose directors were employed by the state.

Fourie and Poggenpoel (2016:6) noted bias or non-competitive procurement of goods and services. In the same vein, an integrated annual report (Auditor-General of South Africa [AGSA] 2019) revealed that the top three projects failed, because of, amongst other factors, poor financial management and a lack of corrective action to address project failures and SCM irregularities. Instances of this nature have motivated protests in the past decade (Nengwekhulu 2009:349). Therefore, neglect of this 'worm' can no longer be afforded. Some of the perpetually reported dilemmas in SCM are issues surrounding human capital, namely its availability, competence and conduct. Meanwhile, a decade ago Crook et al. (2011:443) indicated that there is a positive relationship between human capital and performance of an organisation. In this light, this study reviews the state of human capital in SCM together with the performance of SCM in a quest to ascertain the relationship and impact the two variables have on each other currently in achieving better customer services now and in the future.

\section{Overview of supply chain management}

\section{Supply chain management concept}

Supply chain management can be defined as the collaboration and coordination of 'events or processes' between various partners. It is the management of upstream and downstream affairs with suppliers and customers so as to deliver greatest customer services at the best possible cost (Christopher 2011:4). Nagy (2010:20) asserts that it is solution-driven. Mentzer et al. (2001:18) hold the view that it is the systemic, strategic coordination of traditional business functions aimed at improving the long-term performance of the entire chain. As such, SCM is defined as a set of methodologies utilised to manage person(s) who partake in satisfying customer needs (Du Toit \& Vlok 2014:28). On the other hand, Lee, Kwon and Severance (2007:445) believed that SCM is an integrated management tool that directs information and goods or services flow between different facilities and partners.

According to Marshall et al. (n.d.:4), SCM has been recently at the top of the agenda of both public and private sector organisations with the main aim of balancing demand and supply; however, achieving these results has not been an easy task. Meanwhile, the government of the Republic of South Africa (Republic of South Africa [RSA] 2004) defines:

SCM as an integral part of financial management that seeks to introduce internationally accepted best practices whilst addressing government's preferential procurement policy objectives. Deducing from the above, it can be concluded that SCM is therefore concerned with directing actors and processes in the quest to fulfil customer needs. (p. 2)
As such, SCM could be considered to be the smooth development of synergy innovative activities by which core competencies are built through mining, exploitation and utilisation of own resources.

\section{Supply chain management, total quality management and International Organization for Standardization (ISO) 9000}

According to the definition of SCM as adopted by the public sector, SCM is an integral part of financial management that conforms to internationally best-accepted standards (Migiro \& Ambe 2008:231). It thus becomes vital or rather interesting to understand and know the international standards of financial management. Supply chain management has adopted unique actions and specific reporting standards that are believed to enforce and enhance fairness, equitableness, transparency, competitiveness and costeffectiveness (Republic of South Africa [RSA], 2005:49). Such acts, according to the South African, National Treasury (RSA 2005:49), include the provision of demand management, acquisition management, logistics management, disposal management, risk management and regular assessment of supply chain performance, as separate functions.

Meanwhile, the reporting aspect demands that supply chain reporting be performed in line with International Financial Reporting Standards (IFRS), the rules and regulations of a London-based association called the International Accounting Standard Board (IASB) (Suryantoa \& Komalasarib 2019:171). South Africa subscribed to these standards when, as a country, it adopted SCM in the year 2003. In fact, adoption of and conformance to these standards has become a prerequisite, such that performance of SCM in SA is measured against these standards. All these efforts are geared to achieving total quality management (TQM). According to Gunasekaran and McGaughey (2003) cited in Vanichchinchai and Igel (2009:250), TQM is an action that brings about cost reduction, the construction of high-quality goods and services, customer satisfaction, employee empowerment and the measurement of outcomes. Chang (2009:82) proposed eight principles of International Organization for Standardization (ISO) 9000 standards that have since been adopted by many industries including the public sector, which inform the success experience of organisations in developed countries. These include customer focus, leadership, involvement of people, process management, system management, continual improvement, factual approach to decision-making and mutually beneficial supplier relationships. According to Prajogo, Hou and Han (2012:306), it is assumed that improved internal management processes and better responses to customers or pressures from other external stakeholders can be realised through ISO 9000 standards. However, Prajogo et al. (2012:306) note that since its inception, studies have found inconsistent results pertaining to the relationship between implementation of ISO 9000 and organisational performance. Some studies have found a correlation between the two variables, whilst others have not. For instance, Abusa and Gibson (2013) found no 
difference in the performance for organisations that adopted ISO 9000 from those that did not, except for export growth. Whilst Starke et al. (2012) found that implementation of ISO 9000 impacted on increase in sales revenues, decrease in cost of goods sold or sales revenue and increase in the asset turnover ratios. According to Prajogo et al. (2012:306), it is rather the way in which ISO 9000 is implemented that determines organisational performance. As such, it can be concluded that success depends more on how well an organisation has geared itself up to take advantage of available success tools rather than the tools themselves. Nonetheless, setting up standards remains a critical factor in the performance. According to Chartered Institute of Procurement \& Supply (CIPS) (CIPS 2018:9), the standards support the efficient and cost-effective use of public monies, something the public at large are anxious to see, which, in turn, results in organisational goal achievement. This, according to CIPS, is made possible through building a welltrained and motivated team of procurement and supply staff, therefore achieving cost savings. It is these standards that provide measurable outputs in the procurement and supply function. Such performance is also based on increased ethical conduct, supported by better knowledge and application of associated policies and practices.

\section{Supply chain management predicaments}

In light of the above, it is important to note that from the inception of SCM in SA, a number of academic and nonacademic reviews have been performed. Amongst these, Migiro and Ambe (2008:230) conducted an evaluation of the implementation of public sector SCM and its challenges. They found that almost $80 \%$ of the SCM officials lacked SCM skills, including basic accounting and financial management skills, which resulted in the unsuccessful establishment of cross-functional committees. Again, the non-conformance to law, alleged to have been caused by ambiguous SCM guidelines and a lack of technical skills, was noted by them.

Irregularities such as order split, collusion between suppliers and/or between suppliers and officials and the continued renewal of contracts were also a challenge. Consistent with Migiro and Ambe (2008), Tshamaano's findings noted skill deficiency and collusion. Moreover, corruption, fraud, nepotism, bribery, extortion, conflict of interest, embezzlement, nepotism, favouritism, a lack of monitoring and evaluation, responsiveness and a lack of accountability were other issues found to be evident in SCM (Tshamaano 2012:46). Further, Fourie and Poggenpoel (2016:6) mentioned skills and capacity deficiencies and singled out unfair or uncompetitive procurement, lack of transparency, lack of accountability and resource optimisation as well as non-compliance with policies. As there had been a recurrent finding of non-compliance from the year 2004 to 2011, it is feared that soon, it will become a norm or culture in the public sector.

Other issues include political events that have a damaging impact on SCM (Briano, Caballibi \& Revetria 2009:193). South Africa has been a victim of these dilemmas. Developing countries are said to be more vulnerable to the supply chain risks of political turmoil, rebel activities and post-election violence, bribery, poor transportation infrastructure, corruption and other unethical business practices (Lakovoum, Vlachos \& Xanthopolous 2007). Coupled with this are recent cases of the coronavirus disease 2019 (COVID-19) pandemic scandals, whereby R10.50 billion COVID-19 expenditures has been put under the scrutiny of the Special Investigation Unit (SIU) as there are allegations of corruption (Reuters 2020). The Standing Committee on Public Accounts (Scopa) has called for a speedy review of these issues of alleged corruption (Merten 2020). Having said this, it would be biased not to state some of the opportunities that SCM has brought. This includes, amongst others, promotion of Small, Medium and Micro Enterprises (SMME's) and Historically Disadvantaged Individuals (HDI's) through the application of procurement regulations.

Nevertheless, as this system is not immune to challenges, there is a need to invest in the continuous improvement of strategies. Amongst the five-stage approach of continuous improvement, Bessant et al. (2001), cited in Prado-Prado, García-Arca and Fernández-González (2020:298), propose the active participation of everyone. They emphasise the need for active participation by production workers and personnel at middle management level. As these persons are closer to implementation and worker motivation, they are better positioned to yield better results in SCM than senior management whose roles mainly revolve around definition of strategy and goals. Therefore, the human element becomes a critical factor in achieving better results of SCM in any sector.

\section{Human capital concept}

According to Boon et al. (2017:42), human capital can be defined as the knowledge, experience, skills and other characteristics such as personality traits and interests of each individual in an organisation. These authors identify human capital as a critical construct that differentiates one employee from the other in terms of their knowledge, skills, abilities and other talents. These authors recognise human capital as a catalyst for enhancing an organisation's performance. A similar view is shared by Crook et al. (2011:443) who argue that human capital is mainly regarded as a strategic resource that differentiates or benefits not only one employee from the other but it also differentiates one organisation from another. According to these authors, theories on resource management suggest that structuring, bundling and leveraging the already available resources increase the performance. Managers must do this. It includes ensuring that the right human capital is acquired, developed once employed and utilised to their maximum capability to achieve better results or goals. Therefore, human capital could be defined as an asset that consists of knowledge and skills held by an individual that an organisation can take advantage of to achieve its goals. In fact, such levels of human knowledge and skills are necessary for an organisation to accomplish anything. 


\section{Selecting appropriate human capital}

As many scholars agree that human capital represents a crucial asset for an organisation's success, it becomes important to discuss how such assets are acquired. Personnel recruitment and selection thus becomes the first point of interest because the quality of human capital will be informed by the people an organisation has employed (Chien \& Chen 2008:280).
Recruitment and selection itself begin with postadvertisement. The author performed a random scan into the positions advertised on one of the dominant public sector sites, namely www.dpsa.gov.za, over the past 3 years to ascertain the education, experience and knowledge that the RSA wants in selecting their workforce. Table 1 shows the dominant prerequisites for the appointment of various practitioners in SCM.

TABLE 1: Skills required for supply chain practitioners.

\begin{tabular}{|c|c|c|c|c|c|c|}
\hline Variable & Junior & Admin officer & Senior admin officer & Assistant director & Deputy director & Director \\
\hline Educational & $\begin{array}{l}\text { Grade } 12 \text { or equivalent } \\
\text { qualification }\end{array}$ & $\begin{array}{l}\text { Public management } \\
\text { or supply chain } \\
\text { management }\end{array}$ & $\begin{array}{l}\text { An appropriate B } \\
\text { degree (NQF 7)/3 } \\
\text { year diploma (NQF 6) }\end{array}$ & $\begin{array}{l}\text { B degree (NQF 7)/3 year } \\
\text { diploma (NQF } 6 \text { ) in finance } \\
\text { or equivalent }\end{array}$ & $\begin{array}{l}\text { A 3-year tertiary } \\
\text { qualification in supply } \\
\text { chain management, } \\
\text { finance or procurement } \\
\text { or related equivalent } \\
\text { qualifications }\end{array}$ & $\begin{array}{l}\text { Undergraduate } \\
\text { qualification NQF level } 7 \\
\text { OR equivalent } \\
\text { qualifications as } \\
\text { recognised by SAQA. An } \\
\text { undergraduate } \\
\text { qualification in supply } \\
\text { chain management will } \\
\text { be an added advantage }\end{array}$ \\
\hline Experience & $\begin{array}{l}\text { Experience in supply } \\
\text { chain or procurement } \\
\text { environment will be an } \\
\text { added advantage }\end{array}$ & $\begin{array}{l}\text { One to three years } \\
\text { relevant work experience } \\
\text { in the field of supply } \\
\text { chain management }\end{array}$ & $\begin{array}{l}\text { Minimum } 3 \text { years' } \\
\text { relevant experience } \\
\text { in supply chain } \\
\text { management }\end{array}$ & $\begin{array}{l}\text { Three years relevant } \\
\text { experience }\end{array}$ & $\begin{array}{l}\text { Minimum of } 5 \text { years } \\
\text { relevant experience in } \\
\text { demand management } \\
\text { environment of which } \\
3 \text { years should be at a } \\
\text { junior management level } \\
\text { or assistant director }\end{array}$ & $\begin{array}{l}\text { Five to ten years of } \\
\text { experience as a deputy } \\
\text { director (financial } \\
\text { management or supply } \\
\text { chain management) }\end{array}$ \\
\hline Knowledge & $\begin{array}{l}\text { - PFMA } \\
\text { - TOGIS system } \\
\text { Treasury regulations } \\
\text { and } \\
\text { - Supply chain } \\
\text { management } \\
\text { - Able to work } \\
\text { extended hours } \\
\end{array}$ & $\begin{array}{l}\text { - Computer literacy } \\
\text { - Good knowledge of PFMA, } \\
\text { PPPFA, treasury } \\
\text { regulations, practice notes } \\
\text { and supply chain } \\
\text { management policies and } \\
\text { procedures } \\
\text { Extensive knowledge } \\
\text { - PFMA } \\
\text { - PPPFA } \\
\text { - Treasury regulations } \\
\text { - SCM policy } \\
\text { - Central supplier database } \\
\text { (CSD) and related } \\
\text { legislation } \\
\text { - Willing to work extended } \\
\text { hours where necessary } \\
\text { - Knowledge in buying or } \\
\text { purchasing } \\
\text { - Must be able to work } \\
\text { under pressure } \\
\text { - Must have the ability to } \\
\text { communicate effectively } \\
\text { with clients } \\
\text { - Good planning, organising, } \\
\text { leading and problem- } \\
\text { solving skills } \\
\text { - A valid driver's licence } \\
\text { (attach a copy) } \\
\text { Candidates applying for this } \\
\text { position should be willing to } \\
\text { travel nationwide }\end{array}$ & . & $\begin{array}{l}\text { - Public service regulation } \\
\text { - PFMA } \\
\text { - Treasury regulation } \\
\text { circulary, practice notes } \\
\text { - Computer software } \\
\text { package is essential: MS } \\
\text { package (i.e. Word, Excel, } \\
\text { and PowerPoint), } \\
\text { Microsoft Outlook. }\end{array}$ & $\begin{array}{l}\text { - Supply chain framework } \\
\text { - Preferential procurement } \\
\text { policy framework } \\
\text { - Departmental policies } \\
\text { and procedures } \\
\text { - Project } 16 \text { management } \\
\text { - General management } \\
\text { - Strategic management } \\
\text { - PPPPFA } \\
\text { - PFMA } \\
\text { - Treasury regulations and } \\
\text { other related prescripts, } \\
\text { prescripts relating to } \\
\text { supply chain management } \\
\text { - Government policies } \\
\text { - Legislations and } \\
\text { intergovernmental } \\
\text { relations }\end{array}$ & $\begin{array}{l}\text { - Negotiation } \\
\text { - Relevant acts } \\
\text { - Policies and prescript } \\
\text { PFMA } \\
\text { - Preasury regulations. } \\
\text { - Uublic service policies. } \\
\text { - chain mananagement } \\
\text { principles }\end{array}$ \\
\hline Skills & $\begin{array}{l}\text { - Excellent } \\
\text { communication and } \\
\text { administrative skills } \\
\text { - Good written and } \\
\text { verbal communication } \\
\text { skills } \\
\text { - Good interpersonal } \\
\text { skills } \\
\text { - Good administration } \\
\text { skills } \\
\text { - Able to work under } \\
\text { pressure } \\
\text { - Be reliable and } \\
\text { determined. } \\
\text { - Computer literacy in } \\
\text { MS Excel; Word; and } \\
\text { Outlook }\end{array}$ & 1 & $\begin{array}{l}\text { - Excellent } \\
\text { communication and } \\
\text { administrative skills } \\
\text { - Ability to work in a } \\
\text { team and under } \\
\text { pressure } \\
\text { - Good written and } \\
\text { verbal communication } \\
\text { skills } \\
\text { - Computer literacy } \\
\text { - Excel (intermediate } \\
\text { or advanced) and } \\
\text { general computer } \\
\text { literacy and knowledge } \\
\text { of programmes in MS } \\
\text { Word, Outlook and } \\
\text { PowerPoint } \\
\text { - Knowledge of MS } \\
\text { dynamics CRM will be } \\
\text { an added advantage } \\
\text { - Report writing, } \\
\text { - Good verbal and written } \\
\text { communication skills } \\
\text { - Good problem solving } \\
\text { and analytical skills } \\
\text { - Ability to work in a team } \\
\text { and under pressure } \\
\text { - Valid driver's license }\end{array}$ & $\begin{array}{l}\text { - Good communication } \\
\text { skills } \\
\text { - People management } \\
\text { - Policy analysis and } \\
\text { development } \\
\text { - Risk and compliance } \\
\text { management } \\
\text { - Stakeholder management } \\
\text { and communication } \\
\text { - Good interpersonal } \\
\text { relations and should be } \\
\text { prepared to work under } \\
\text { pressure } \\
\text { - Knowledge and } \\
\text { understanding of } \\
\text { leadership } \\
\text { - Delegation and } \\
\text { empowerment } \\
\text { - Report writing } \\
\end{array}$ & $\begin{array}{l}\text { - Proven sound } \\
\text { management and } \\
\text { administrative skills } \\
\text { - Change management } \\
\text { skills. Good facilitation } \\
\text { and presentation skills } \\
\text { - Communication (written } \\
\text { and verbal) } \\
\text { - Analytical thinking } \\
\text { - Good computer literacy } \\
\text { in Microsoft Office suite } \\
\text { (Word, Excel and } \\
\text { - Power-Point) } \\
\text { pressure work under } \\
\text { tight deadlines } \\
\text { - Leadership } \\
\text { - Negotiating } \\
\text { - Facilitation } \\
\text { - Computer literacy } \\
\text { - Presentation } \\
\text { - Innovative } \\
\text { - Analytical }\end{array}$ & $\begin{array}{l}\text { - Strategic capability and } \\
\text { leadership } \\
\text { - People management } \\
\text { and empowerment } \\
\text { - Project management } \\
\text { - Financial management } \\
\text { - Change management } \\
\text { - Computer literacy } \\
\text { - Knowledge } \\
\text { management } \\
\text { - Service delivery } \\
\text { innovation } \\
\text { - Problem solving and } \\
\text { analysis } \\
\text { - Client orientation and } \\
\text { customer focus } \\
\text { - Communication } \\
\text { - Public service } \\
\text { - Procedures and analytic } \\
\text { skills }\end{array}$ \\
\hline
\end{tabular}

SAQA, South African Qualifications Authority; NQF, National Qualifications Framework; LOGIS, Logistical Information System; PPPFA, Preferential Procurement Policy Framework Act; PFMA, Public Finance Management Act; SCM, Supply Chain Management; CRM, Customer Relations Management; MS, Microsoft Office. 
Given the above, it is acknowledged that the government of SA recognises the need for world-class skills, namely good or excellent communication skills, both verbal and written, teamwork, computer literacy and negotiation skills (Giunipero \& Pearcy 2000, quoted in Prajogo \& Sohal 2013:1534).

Teamwork is defined by Giunipero and Pearcy (2000), quoted in Prajogo and Sohal (2013:1534) as having the ability to lead, make decisions, be influential and compromise where necessary.

This is necessary because SCM, as defined by Nagy (2010:20), is an integrative management philosophy that requires collaboration amongst partners to establish pioneering solutions so as to provide sound customer services. As such, SCM practitioners should be able to work within a network of such bodies. Skills such as communication and negotiation become vital as one interacts with other partners, more so during contract negotiations and awards.

Communication skills entail the ability to do presentations, public speaking, listening and writing. Noted as well are the requirements for potential candidates to possess skills or the ability to work under pressure.

This requirement could suggest that SCM is a heavy task that involves dealing with constraints that are at times outside of one's control. These may include resource or time constraints, difficult tasks or insufficient knowledge to complete tasks, or unforeseen changes or problems, or it could be slavery. Nevertheless, end-customer needs ought to be satisfied. Therefore, decision-making skills in SCM are always necessary.

Additionally, teamwork and problem-solving abilities are amongst the skills suggested by Wagner, Sancho-Esper and Rodriguez-Sanchez (2020:3), and these are set as requirements for the public sector SCM practitioners. Surprisingly, as shown in Table 1, the entry requirement is set at Grade 12. This can indicate that SCM is not regarded as a specialised function in the public sector but is considered as any other administrative task that can be learned and carried out without formal post-matric education; or this could be a strategy to lower labour costs. The sad part of this is that a huge number of students in this field are graduate from tertiary institutions across the world (Machin \& McNally 2007:3). This includes a number of graduates with SCMrelated academic qualifications produced by universities such as University of South Africa (UNISA), University of KwaZulu-Natal (UKZN), University of Zululand (UZ), Mangosuthu University of Technology (MUT) and Durban University of Technology (DUT). Seemingly, that is not what the government of RSA requires. Could there be mistrust or relevancy issues between teaching and learning versus the skill demands of the labour market? On the other hand, formal post-matric education attainable at tertiary institutions or technical and vocational education and training (TVET) are presumed to have a role of 'skilling'. As such, it could be considered a vital asset to bridging the knowledge gap and ensuring preparedness for the work place.
Given the above, the state may be deprived of the opportunity to benefit from the learned skills from tertiary and TVET institutions from the onset of the employ of its human capital.

\section{Developing human capital}

Human capital resources are defined by Barney (1991:101) as inclusive of 'the training, experience, judgement, intelligence, relationships and insights of individual managers and workers in a firm'. Further, organisational capital resources are inclusive of a 'firm's formal reporting structures, its formal and informal planning, controlling and coordinating systems as well as informal relations among groups within a firm and those in its environment'.

Human capital can therefore be described as the personnel of an organisation who works realising the goals of the organisation. However, having the correct or incorrect human capital on an organisation's payroll may not suffice in the attainment of the organisational goals. Whilst Handfield et al. (2011:21) allude to the importance of the quality of employees to an organisation's performance, it should be noted that some effort is required of an organisation to ensure that its labour force remains relevant and has the capacity to support the achievement of the goal. This, according to Nkwanyana (2017:9), can be achieved through training, whilst Obi-Anike and Ekwe (2014:68) believe that it can be performed through attitudes and behavioural change. Overstreet et al. (2019:42) agree that SCM is actually about the people who make up the supply chain workforce. It is, in fact, the ever-increasing level of knowledge, skills and abilities that matters in today's market space and to the success of an organisation, and this comes with the people we employ. Delery and Roumpi (2017:6) warn that human capital is not a definite resource for an organisation because good employees can leave their employers at any time and thus take with them their treasured human capital. Campbell, Coff and Kryscynski (2012:3) agree and consequently identify general human capital and firm-specific human capital. They define general human capital as the knowledge, skills and abilities that are broadly applicable to any organisation, whilst firm-specific human capital is the knowledge, skills and abilities that are specific to a particular organisation. General human capital includes skills such as education, basic reading, writing and arithmetic skills; these are easily deployable in many organisations, whilst firm-specific human capital has limited applicability outside a core organisation. Both general human capital and firm-specific human capital are critical. As a relationship exists between human capital and an organisation's performance (Crook et al. 2011:443), adequate care must be taken to develop human capital. As such it could be argued that a strategy related to human resource management (HRM) should be in place to design and implement a set of internally consistent policies and practices that are geared to achieving an organisation's objective through human capital. In the same vain, Delery and Roumpi (2017:6) mention that in the absence of HRM practices that generate the appropriate levels of motivation and opportunities, human capital would be unable to lead to 
the desired goal. This means that an organisation must instil a learning culture wherein skills are created and acquired, knowledge transferred, and, when needed, behaviour is modified to reflect new knowledge and insights of an organisation (Overstreet et al. 2019:44). In view of the above, it can be concluded that goal achievement of an organisation is dependent not only on human capital availability but also on how best this is managed; only then will it, in fact, result in the realisation of the organisational goal.

\section{Leveraging human capital}

Having mentioned the need for an organisation to first employ the correct human capital and further develop this for the realisation of the organisational goal, it is also crucial to mention the last aspect that supports an organisation in achieving its goal through human capital, and that is leveraging human capital. This implies the use of human capital to the maximum capability to achieve better results or goals. It is the ability of an organisation to influence its employees so that it can control results. In line with this, the author identified high-performance work systems (HPWS), as reported by Aryee et al. (2013:2), as an SHRM tool that could be used by organisations to take advantage of human capital to create and achieve a sustainable competitive advantage (SCA). This means an organisation should find ways to harness competitiveness through its employees and their various skill sets (Kehle 2016:15). David (2011:42) contends that organisations should incorporate their employee's core competencies and intangible resources in their strategic thinking when seeking to retain a competitive advantage. This was also noted by Henry (2013:85), who states that employee competencies are the embodiment of the organisation's strategically relevant skill sets and pertinent knowledge linked to the achievement of organisational objectives. Similarly, Nickerson and Zenger (2004) contend that:

$[T]$ he firm acknowledges that one central task of the manager is to accumulate and protect valuable knowledge or capability and that such knowledge or capability defines a firm's capacity to efficiently convert its inputs to valuable outputs through Resource-based view (RBV). (p. 1)

\section{Theoretical grounding}

This research is grounded in the RBV theory. This theory assists in explaining the connections between human capital and operational performance of an organisation. Theories represent ideologies established to describe a group of realities, especially if such ideologies have been tested and found acceptable to make a prediction about a phenomenon (Nyaga 2015:240).

\section{Resource-based view}

The resource-based view (RBV) can be defined as a group of resources connected to an organisation for a particular time period (Lockett, Thompson \& Morgenstern 2009:10).

These resources could include but are not limited to physical assets, capabilities, organisational processes and information.
According to Francisco (2015:50), RBV aims to enhance competencies and roles of these resources in the effort to improve the SCA and performance (Yang 2009:1260). Most importantly, resources alone are inadequate; it is their capacity to be created, and their functionality, efficiency and effectiveness when combined that will yield SCA (Lockett et al. 2009:10). Hence, the need for leveraging human capital arises. Resource-based view's strategic goal is to enhance the role of these resources and capabilities in the interest of achieving SCA for the organisation (Francisco 2015:50) and improving performance (Yang 2009:1260). Barney (1991), cited in Sarkis, Zhu and Lai (2011:4) describes these resources as treasured, uncommon, improperly imitable and nonsubstitutable. Treasured resources are those that are used to take advantage of opportunities and overcome threats to the organisation, whilst uncommon resources are those that are scarce to be found by current and future competitors (Lockett et al. 2009:11). Imitability refers to the degree to which a product can be falsified, whilst the non-substitutability of resources implies that one resource cannot be simply swapped (or substituted) for another. Lockett et al. (2009:10) add that having resources is insufficient. Having SCA is also dependent on the resources' functionality, their efficiency and effectiveness when combined, and their capacity to be created. Therefore, where government departments appreciate the RBV requirements, they would conduct a screening of their labour force to understand and build their competencies through various enhancement methods. By this, a department will be confident that they have improperly imitable, treasured, uncommon and non-substitutable labour force that immensely contribute to SCA of a department. Having said these, this research article's main objective is to (1) ascertain the suitability of human capital within SCM for the national government to achieve better customer services. It will achieve this by a concurrent test of the nature of human capital and the state of SCM thereof as a consequence of the nature of available human capital.

\section{Research method and design}

In order to gain in-depth insight into the matter under investigation, a case study was conducted. Case studies normally involve a single organisation as a population of study, and its findings can be extrapolated to other organisations of a similar nature. According to Crowe et al. (2011:1), this makes it favourable for theory generation and theory testing where little is known about a phenomenon (Kumar 2011:335). As such, it is believed that the aspect of human capital and performance would be best described through a case study. The authors selected one of the national departments in the province of KwaZulu-Natal (KZN) in SA as a population of study. Of an estimated 232 persons in the population, 129 persons participated in this study; this included 19 middle managers, 16 supervisors and 94 junior staff members, resulting in an overall response rate of $86 \%$ comparing to a sample of 150 . Utilising purposive sampling (Bless, Higson-Smith \& Sithole 2013:172), only persons involved in the SCM processes were considered and finally included in the sample. 
Quantitative primary data were collected using a five-point Likert-scale questionnaire. According to Sekaran (2006:236), a questionnaire is a measuring instrument with a predesigned set of written questions to be answered by subjects. On the one hand, the author developed closed-ended questions that were intended to ascertain about the availability of sufficient human capital, whether they have been adequately trained and if they have sufficient knowledge to carry out their tasks. On the other hand, the author asked participants if SCM is performing well in satisfying end customer need as well as whether or not it has led to a remarkable positive results to betterment of service delivery. These questions through questionnaire were piloted with a small group of persons to ensure relevance, accuracy, completeness and that it was free from error. Therefore, it can be regarded as a valid and a reliable measure.

Questionnaires were sent using blind copy (bcc) on email so as to avoid possible conspiracy of answers from respondents. These were also received back via email or fax; following this, they were coded, such as M1, S1 and J1, to uphold the principle of confidentiality. Thereafter all data received were validated for completeness; incomplete questionnaires were discarded whilst all those that conformed progressed through the stage of analysis using the Statistical Package of Social Sciences (SPSS) version 23.0. Numerical data in total sums and percentages as presented by SPSS were further examined to reflect meanings. First individual data of focus areas of study, namely nature of human capital and states of SCM, were analysed and presented individually through univariate analysis. The two results were later compared to ascertain what is the connection that one has on the other and this was achieved through bivariate analysis. This approach was deemed suitable to find honest opinions about the two variables separately and allow the findings to portray the impact of one variable to the other.

\section{Ethical consideration}

A level 2 ethical clearance was obtained from DUT to conduct this research (reference number FREC 231/216FREC).

\section{Results}

The results in Figure 1 illustrate the findings of this research study in relations to the nature of human capital available to support national government to achieve its mandate of better customer services in the SCM as viewed by participants of the studied organisation. On the other hand, Figure 2 shows the current states of SCM assumed as a consequence of current factors including that of human capital. Meanwhile, Figure 3 portrays a comparison between the nature of human capital and the states of SCM.

The study found some connection between the nature of human capital and the results of SCM within national government. As a test was made to ascertain the investment in human capital as well as the outcome and/or results of SCM, a clear view was presented regarding unavailability of adequate training and adequate human capital, with scores of $62.8 \%$ and $50.4 \%$, respectively. Just less than half the number of participants, namely $n=60(46.6 \%)$, believed that SCM has resulted in a remarkable positive outcome in relation to public service delivery, whilst $n=51$ (39.5\%) were unsure of this, and $n=18(14 \%)$ disagreed with this statement. On the one hand, performance of SCM to meet the demands of end users was rated by at least half of the

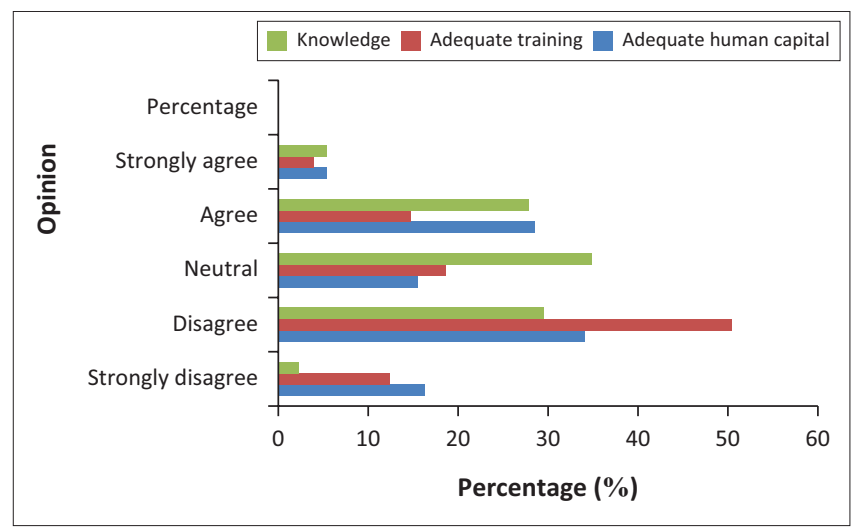

FIGURE 1: Nature of human capital.

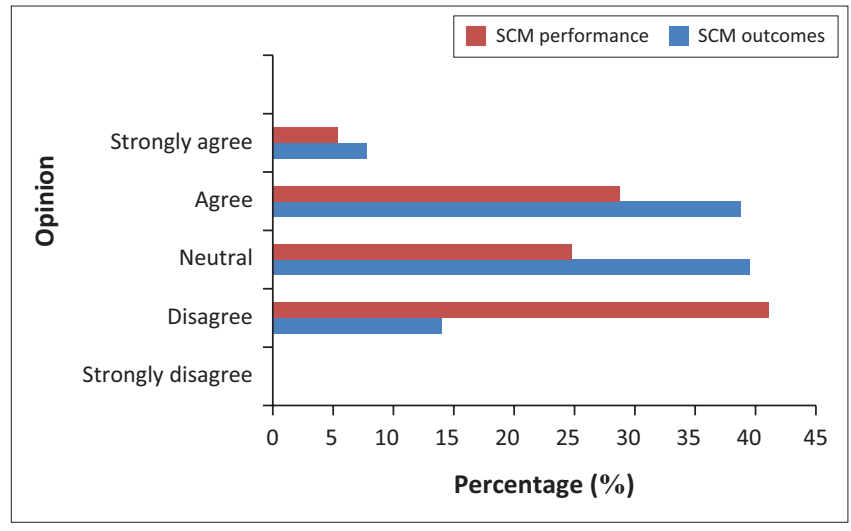

SCM, supply chain management.

FIGURE 2: The states of supply chain.

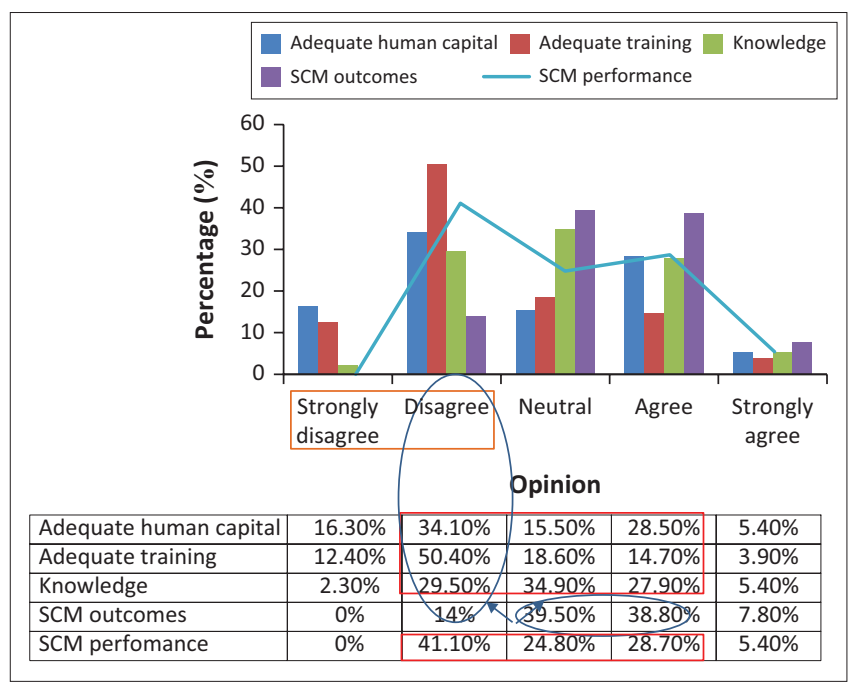

SCM, supply chain management.

FIGURE 3: Comparison between human capital and supply chain management results. 
participants ( $n=53 ; 41.1 \%)$ as not being in order, $n=32$ (24.8\%) were unsure, whilst only $n=37(28.7 \%)$ and $n=7$ (5.4\%) were confident that SCM is performing well. As such, assumptions can be made that SCM's performance is rather in an unstable state. For instance, results of the study showed that $n=45(34.9 \%)$ respondents were uncertain if the role-players possess adequate knowledge in carrying out their tasks, whilst $n=41(31.8 \%)$ believed that they had inadequate knowledge. On the other hand, $n=43$ (33.3\%) were confident (agreed and strongly agreed) that the roleplayers had adequate knowledge. A relatively equal split in views expressed in favour of the statement, those not in favour of it and those that opted not to express their view is assumed to be an indicator of mayhem in this aspect. The author could assume therefore that the little knowledge that existed was by pure 'default', as an artefact of the reasonable amount of time that the majority of officials $(n=$ $81 ; 61.9 \%$ ) have spent in their positions. This is a worrying factor considering the assertion by Sarkis et al. (2011:4) that purchasing practitioners have powers over large sums of monies, including having some influence on which suppliers to award works. When less knowledgeable persons are tasked with the responsibility to influence decision-making, this could be a recipe for disaster, thus causing major problems in this sector. Another worrying aspect is that, there are arguable results related to what participants believe has been the outcome of SCM inception in this sector. Although $n=60$ (46.6\%) participants maintained that SCM has resulted in a remarkable positive outcome in relation to public service delivery, a relatively disturbing number $(n=51 ; 39.5 \%)$ was unsure of this, whilst $n=18(14 \%)$ disagreed with this statement. On the other hand, it was found that little training exists because more than half of the respondents $(n=65 ; 50.4 \%)$ disagreed on having received adequate training, which was supported by $n=16$ (12.4\%) respondents, who strongly disagreed that they had received adequate training. This resonates with a similar finding of lack of staff training highlighted by Corominas (2013:6833) and Tshamaano (2012:46). This is rather surprising because the accounting officer (AO) must ensure, amongst others, training of SCM officials (RSA 2004:50). Further, the National Treasury is mandated to assist organs of the state to build capacity through training (RSA 2004:50). Skill deficiency issues have been a problem for several years. A report of the shortfall in a wide range of skills in SCM was reported (Ellinger \& Ellinger 2014:119), aggravated by a lack of resources and a lack of strategic prioritising of SCM in functionality. Many organisations were reported to be more focused on building relations with suppliers and customers as well as cost saving more than anything else add the preceding authors.

Manjate (2019:21) also noted a lack of skills in SCM. According to Piernaar (2019:33), this causes a challenge of unintended errors. Although institutions of higher learning such as universities, universities of technologies and TVET colleges could have been a partial solution to providing generic SCM skills, it was found that post-matric qualifications are not a requirement for appointments in this field as reflected in Table 1. This is a worrying factor in relation to its impact on the current performance as well as the future sustainability of the performance. For instance, it has been found that no adequate training is provided to staff; meanwhile, staff is appointed without relevant skills from institutions of higher learning.

Firstly, controversial challenges may ensue and the sector may currently be at risk because decision-making and influential actions rest upon persons who have neither formal learning nor training in the field because entrylevel officers perform the majority, or rather the risky part, of the work, such as request for quotations (RFQs). Secondly, this sector may face future dilemmas in not attracting the correct candidates to fill their supervisory positions (Admin Officers upwards); because they may not have a pool of qualifying candidates internally as a result of employing persons without post-matric qualifications in their entry-level positions as their advertisement of positions suggests in Table 1. This could later result in having many personnel at entry-level positions that are not promotable to senior positions. This could further result in low morale, low productivity and thus poor performance, which may yield failure of an organisation. Another worrying aspect is that of workforce shortage, deduced from post advertisements wherein the 'ability to work under pressure' is continuously repeated. This was confirmed by this study, where only $n=37$ (28.7\%) agreed to the statement that there is adequate human capital in the organisation (statement 4). Only $n=7$ (5.4\%) strongly agreed and $n=21(16.3 \%)$ strongly disagreed, whilst almost half $(n=44 ; 34.1 \%)$ disagreed with the statement. This finding is in line with findings of Fourie and Poggenpoel (2016:6) which state that there is a capacity deficiency in the public sector. This workforce deficiency, Husby (2007:53) stated, is a constraint that, according to Ainapur, Singh and Vittar (2012:99), hinders the attainment of organisational goals. This finding indicates that the structuring of human capital, as suggested by human capital theory, is not in place. It is therefore not surprising that performance of SCM to meet the demands of end users is rated by at least half of the participants $(n=53 ; 41.1 \%)$ as not in order, whilst $n=32(24.8 \%)$ opted to remain neutral in this matter. Only $n=37(28.7 \%)$ and $n=7(5.4 \%)$ believe that the SCM system is operating or performing well in meeting the demands of end users. This supports the claims of Crook et al. (2011:443) and Handfield et al. (2011:21) who contend that performance is linked to human capital. Therefore, having weak human capital is likely not to yield desirable performance. Nevertheless, there is hope in transformation of the above because a relatively reasonable number of participants $(n=60 ; 46.6 \%)$ mentioned that SCM has resulted in a remarkable positive outcome in relation to public service delivery. However, the fact that $n=51(39.5 \%)$ of the participants were unsure of this, and $n=18(14 \%)$ reject this assertion is rather worrying. 


\section{Discussion}

Results of the study confirm the view of many scholars that a relationship exists between performance and human capital. However, this study also indicates clearly that there are concerns about human capital unavailability as well as inadequate training in this sector. Only $n=37$ (28.7\%) agreed to the statement that there is adequate human capital in the organisation, $n=7(5.4 \%)$ strongly agreed and $n=21(16.3 \%)$ strongly disagreed, whilst almost half $(n=44 ; 34.1 \%)$ disagreed with the statement. Again, unavailability of adequate training was expressed by a high number $(n=71 ; 62.8 \%)$ of respondents who disagreed and highly disagreed accordingly that they were adequately trained. The same can be traced back to the times of Tshamaano (2012:46) and Corominas (2013:6833), where lack of staff training was highlighted despite the National Treasury's directive that directs AOs to ensure that training is provided to SCM personnel (South Africa 2004:50). Another troubling aspect is that where training is not adequately provided, staff is most likely also lack skills, and the unavailability of skills, according to Piernaar (2019:33), presents the likelihood for errors.

As a result, performance of SCM to meet the demands of end users is rated by at least half of the participants $(n=53 ; 41.1 \%)$ as not in order, $n=32(24.8 \%)$ are unsure, whilst only $n=37$ $(28.7 \%)$ and $n=7(5.4 \%)$ are confident that SCM is performing well. Nonetheless, a relatively reasonable number of participants $(n=60 ; 46.6 \%)$ maintained that SCM has resulted in a remarkable positive outcome in relation to public service delivery; a note of warning, however, in light of the fact that $n=51(39.5 \%)$ of the participants were unsure of this, and $n=$ $18(14 \%)$ disagreed with this statement. Having said these, it has been noted that the use of questionnaires, especially closed-ended questions were rather not favourable to this study. Such that although a test was made to detect human capital standing, performance and outcome of SCM inception. It is rather not known if performance and SCM outcomes are, in fact, affected by human capital dilemmas. Those tests were performed independently of each other. Although this study links the three constructs, respondents may have not meant the one caused the other. Other factors, not even covered in this study, may be the actual cause of underperformance and current results of SCM. As such empirically, it remains vague as to whether is it lack of human resources availability, lack of the knowledge and skills equates to undesirable outcomes and weak performance. Therefore, it is recommended that future research considers the use of techniques such as interviews or focus group as means for data collection. This will enable researcher to obtain better insights on how and what participants believe is a link between the three constructs.

\section{Conclusion}

The study aimed to examine human capital and its relationship with improved results of SCM in the public sector, and national government so as to ascertain the current state of human capital investments in SCM versus SCM performance in the public sector. In this study, current situations and dilemmas faced in SCM are explicated, providing new knowledge that could capacitate and support this sector in sound decision-making. The study's findings do link human capital and performance of SCM. It shows that where there is no, or insufficient investment in human capital, performance is likely to be negatively impacted.

Notwithstanding, some light exists as some participants believed that SCM, in general, brought about some remarkable changes in this sector. Eliminating the weaknesses of the identified situations and building onto the current strengths would create a more favourable space for better performance of SCM in the public sector.

\section{Acknowledgements}

The author would like to acknowledge the support and guidance provided by Dr Paul Issock of Osmoz Consulting Pty. Ltd. for academic guidance in this article as well as Karen Buckenham for her language editing, most importantly, an institution from which data were collected and the participants who voluntarily agreed to providing inputs on the matter under investigation despite their busy schedule and status. The author is profoundly great full to all.

\section{Competing interests}

The author has declared that no competing interests exist.

\section{Author's contributions}

N.S.N. was the sole researcher of this article.

\section{Funding information}

N.S.N. received a postgraduate support grant from the Durban University of Technology (DUT) where she was a student.

\section{Data availability}

The data that support the findings of this study are available from the corresponding author, N.S.N., upon reasonable request, who would provide due reference.

\section{Disclaimer}

The views and opinions expressed in this article are those of the author and do not necessarily reflect the official policy or position of any affiliated agency of the author.

\section{References}

Abusa, F. \& Gibson, P., 2013, 'Experiences of TQM elements on organizational performance and future opportunities for a developing country', International Journal of Quality and Reliability Management 20(9), 920. https://doi. org/10.1108/IJQRM-07-2012-0106

Ainapur, B., Singh, R.K. \& Vittar, P., 2012, 'Strategic study on enhancement of supply chain performance', International Journal of Business Insights and Transformation 5(1), 98-106.

Aryee, S., Walumbwa, F.O., Seidu, E.Y. \& Otaye, L.E., 2013, 'Developing and leveraging human capital resource to promote service quality: Testing a theory of performance', Journal of Management 42(2), 480-499. https://doi. org/10.1177/0149206312471394 
Auditor-General of South Africa, 2019, Enhanced mandate for enhanced accountability, viewed 29 November 2019, from http://pmg.org.za/committee-meeting/29037.

Barney, J., 1991, 'Firms resources and sustained competitive advantage', Journal of Management 17(1), 99-120. https://doi.org/10.1177/014920639101700108

Bizana, N., Naude, M.J. \& Ambe, I.M., 2015, 'Supply chain management as a contributing factor', Journal of Contemporary Management 2, 664-683, viewed 07 October 2020 from http://hdl.handle.net/10500/22573.

Bless, C., Higson-Smith, C. \& Sithole, S.L., 2013, Fundamentals of social research methods: An African perspective, 5th edn., Juta, Cape Town

Boon, C., Eckardt, R., Lepak, D.P. \& Boselie, P., 2018, 'Integrating strategic human capital and strategic human resource management', The International Journal of Human Resource Management 29(1), 34-67. https://doi.org/10.1080/09585192. Human Resource

Briano, E., Caballini, C. \& Revetria, R., 2009, 'Literature review about supply chain vulnerability and resiliency', in proceedings of the 8th WSEAS International conference on system science and simulation in engineering, Genoa, Italy, World conference on system science and simulation in engineering, Genoa, Italy, World
Scientific and Engineering Academy and Society (WSEAS), viewed 07 November 2020, pp. 191-197.

Campbell, B.A., Coff, R. \& Kryscynski, D., 2012, 'Rethinking sustained competitive advantage from human capital', Academy of Management Review 37(3), 376-395. https://doi.org/10.5465/amr.2010.0276

Chang, G., 2009, 'Total quality management in supply chain', International Business Research 2(2), 82-85. https://doi.org/10.5539/ibr.v2n2p82

Chien, C.F. \& Chen, L.F., 2008, 'Data mining to improve personnel selection and enhance human capital: A case study in high-technology industry', Expert System with Applications 34(1), 280-290. https://doi.org/10.1016/j.eswa.2006.09.003

Christopher, M.I., 2017, Logistics \& supply chain management, Prentice Hall, Pearson Education Limited.

CIPS, 2018, Introducing: The global standard for procurement and supply, viewed 20 November2020 from https://www.cips.org/Documents/Global_Standard/2018\%20 update/CIPS\%20Global_Standard_UPDATE_96pp_A4_1018_WEB.pd

Corominas, A., 2013, 'Supply chain: What they are and the new problems they raise?', International Journal of Production Research 51(23-24), 6828-6835. https://doi. org/10.1080/00207543.2013.852700

Crook, T.R., Todd, S.Y., Combs, J.G., Woehr, D.J. \& Ketchen, Jr. D.J., 2011, 'Does human capital matter? A meta-analysis of the relationship between human capital and firm performance', Journal of Applied Psychology 96(3), 443-456. https://doi. org/10.1037/a0022147

Crowe, S., Creswell, K., Robertson, A., Husby, G., Avery, A. \& Sheikh, A., 2011, 'The case study approach', BMC Medical Research Methodology 11(1), 100. https:// doi.org/10.1186/1471-2288-11-100

David, F.R., 2011, Strategic management: Concepts and cases, 13th edn., Prentice Hall, New York, NY.

De Lange, S., 2011, 'Irregular state expenditure jumps 62\%', Business Day, viewed 16 July 2016 from http://www.smartprocurement.co.za/irregular_state_expenditure jumps_62.php

Delery, J.E. \& Roumpi, D., 2017, 'Strategic human resource management, human capital and competitive advantage: Is the field going in circles?', Human Resource Management Journal 27(1), 1-21. https://doi.org/10.1111/1748-8583.12137

Du Toit, D. \& Vlok, P.J., 2014, 'Supply chain management: A framework of understanding', South African Journal of Industrial Engineering 25(3), 25-38. https://doi.org/10.7166/25-3-743

Ellinger, A.E. \& Ellinger, A.D., 2014, 'Leveraging human resource development expertise to improve supply chain managers' skills and competencies', European Journal of Training and Development 38(1/2), 118-135. https://doi.org/10.1108/ Journal of Training and

Fourie, D. \& Poggenpoel, W., 2016, 'Public sector inefficiencies: Are we addressing the root causes?', South African Journal of Accounting Research 31(3), 169-180. https://doi.org/10.1080/10291954.2016.1160197

Francisco, J., 2015, 'Resource-based view and dynamic capabilities: Achieving competitive advantage through internal resources and competences', Budapest

Handfield, R.B., Monczka, R.M., Giunipero, L.C. \& Patterson, J.L., 2011, Sourcing and supply chain management, 5 th edn., South-Western Cengage Learning, Boston, MA.

Henry, L., 2013, 'Intellectual capital in a recession: Evidence from UK SMEs', Journal of Intellectual Capital 14(1), 84-101. https://doi.org/10.1108/14691931311289039

Husby, P., 2007, 'Competition or complement: Six sigma and TOC', Material Handling Management 62(10), 51-55.

Jiang, C., 2020, 'Influencing factors of the performance of supply chain management: An analysis from the perspective of psychology', Revista Argentina de Clínica Psicológica 29(1), 960-965. https://doi.org/10.24205/03276716.2020.133

Kehle, K.E., 2016, 'Strategic intellectual capital management: Case study in the banking and financial services sector in Zimbabwe', Master's dissertation, pp. 1-198, University of KwaZulu Natal, Durban.

Kshetri, N. \& Voas, J., 2019, 'Supply chain trust', IT Professional 21(2), 6-10. http://doi. org/10.1109/MITP.2019.2895423

Kumar, R., 2011, Research methodology: A step-by-step guide for beginners, 3rd edn., Sage, London.

Lakovou, E., Vlachos, D. \& Xanthopolous, A., 2007, 'An analytical methodological framework for the optimal design of resilient supply chains', International Journal of Logistics Economics and Globalisation (IJLEG) 1(1), 1-20. https://doi. org/10.1504/IJLEG.2007.014498
Lee, C.W., Kwon, I.G. \& Severance, D., 2007, 'Relationship between supply chain performance and degree of linkage among supplier internal integration and customer', Supply Chain Management: An International Journal 12(6), 444-452. customer', Supply Chain Management: An Intern
https://doi.org/10.1108/13598540710826371

Lockett, A., Thompson, S. \& Morgenstern, U., 2009, 'The development of the resourcebased view of the firm: A critical appraisal', International Journal of Management Reviews 11(1), 1468-2370. https://doi.org/10.1111/j.1468-2370.2008.00252.x

Machin, S. \& Mcnally, S., 2007, Tertiary education systems and labour markets, Orginisation for Economic co-operation and Development (OECD), Paris.

Manjate, O., 2019, 'Investigating procurement challenges within three provincia department in KwaZulu Natal', Master's dissertation, University of KwaZulu Natal, Durban.

Marshall, R.E., Gooley, T.B., Wayne, M., Frazelle, E., Hammer, M.M. \& Finley, J., n.d., 'Supply chain management: Analyzing industry and air force metrics globa logistics support - The GLSC: Operational supply chain management', Air Force Journal of Logistics xxxi(3), 1-16.

Mentzer, J.T., DeWitt, W., Keebler, J.S., Min, S., Nix, N.W. \& Smith, C.D., 2001, 'Defining supply chain management', Journal of Business Logistics 2(22), 1-25. https://doi. org/10.1002/j.2158-1592.2001.tb00001.x

Merten, M., 2020, 'SIU probes R5.08-bn in questionable covid-19 tenders, while lists of PPE contracts emerge', viewed 15 November 2020, from https://www. dailymaverick.co.za/article/2020-08-20-siu-probes-r5-08-bn-in-questionablecovid-19-tenders-while-lists-of-ppe-contracts-emerge/.

Migiro, S.O. \& Ambe, I.M., 2008, 'Evaluation of the implementation of public sector supply chain management and challenges: A case study of central district municipality, North West province, South Africa', African Journal of Business Manicipality, North West provin

Nagy, J., 2010, 'Types of supply chains and tools for management: Empirical study', Doctorate dissertation, Corvinus University of Budapest, Budapest.

Nengwekhulu, R.H., 2009, 'Public service delivery challenges facing the South African public service', Journal of Public Administration 44(2), 341-363.

Ngobeni, S.A., 2011. 'An analysis of the tender process in national government in South Africa', Doctorate dissertation, North-West University, Potchefstroom.

Nickerson, J.A. \& Zenger, T.R., 2004, 'A knowledge-based theory of the firm: The problem-solving perspective', Organization Science 15(6), 617-632. https://doi. problem-solving perspective',
org/10.1287/orsc.1040.0093

Nkwanyana, B., 2017, 'An analysis of training and development in the public sector: A case study of government communication and information system in the KwaZuluNatal province', Master's dissertation, University of KwaZulu-Natal, Durban.

No author, 2020, Forensic investigations into alleged irregular procurement of personal protective equipment and blankets, viewed 10 November 2020, from https://www.gov.za/speeches/premier-sihle-zikalala-forensicinvestigationsalleged-irregular-procurement-personal.

Nyaga, J., 2015, 'Non-financial reward and employee retention in private primary schools in Kenya (Kiambu county)', International Journal of Management and Commerce Innovations 3(1), 240-254.

Obi-Anike, H. \& Ekwe, M., 2014, 'Impact of training and development on organizational effectiveness: Evidence from selected public sector organizations in Nigeria', European Journal of Business and Management 6(29), 66-75.

Overstreet, R.E., Skipper, J.B., Huscroft, J.R., Cherry, M.J. \& Cooper, A.L., 2019, 'Multistudy analysis of learning culture, human capital and operational performance in supply chain management: The moderating role of workforce level', Journal of Defense Analytics and Logistics 3(1), 41-59. https://doi.org/10.1108/JDAL-11 2018-0017

Piernaar, A., 2019, 'Exploring behavioural challenges in supply chain management of George municipality in order to function optimally', Master's dissertation, University of Stellenbosch, Cape Town.

Prado-Prado, J.C., García-Arca, J. \& Fernández-González, A.J., 2020, ‘People as the key factor in competitiveness: A framework for success in supply chain management', Total Quality Management \& Business Excellence, 31(3-4), 297-311. https://doi. org/10.1080/14783363.2018.1427499

Prajogo, D. \& Sohal, A., 2013, 'Supply chain professionals: A study of competencies, use of technologies and future challenges', International Journal of Operations \& Production Management 33(11-12), 1532-1554. https://doi.org/10.1108/ IJOPM-08-2010-0228

Prajogo, D., Huo, B. \& Han, Z., 2012, 'The effects of different aspects of ISO 9000 implementation on key supply chain management practices and operational performance', Supply Chain Management: An International Journal 17(3), performance', Supply Chain Management: An Inter
306-322. https://doi.org/10.1108/13598541211227135

Republic of South Africa, 2004, National treasury guide for accounting authorities, Government Printer, Pretoria.

Republic of South Africa, National Treasury, 2005, National treasury regulations, Department of National Treasury, Pretoria.

Reuters, 2020, 'South Africa investigates COVID-19 contracts for corruption', viewed 04 December 2020, from https://www.engineeringnews.co.za/article/southafrica-investigates-covid-19-contracts-for-corruption-2020-10-20/rep_id:4136

Sarkis, J., Zhu, Q. \& Lai, K., 2011, 'An organizational theoretic review of green supply chain management literature', International Journal of Production Economics 130(1), 1-15. https://doi.org/10.1016/j.ijpe.2010.11.010

Sekaran, U., 2006, Research methods for business: A skill building approach, John Wiley and Sons, New Delhi.

Setino, R., 2018, 'Alignment of Supply Chain Management practices with policies and regulations in State Owned Entities in South Africa', PhD thesis, University of South Africa. 
Starke, F., Eunni, R.V., Manoel Martins Dias Fouto, N. \& Felisoni de Angelo, C., 2012, 'Impact of ISO 9000 certification on firm performance: Evidence from Brazil', Management Research Review 35(10), 974-997. https://doi.org/10.1108/01409171211272697

Stemele, B.M., 2009, 'Assessing good governance in procurement at Lejweleputswa district municipality', Master's dissertation, University of Stellenbosch, Stellenbosch

Suryanto, T. \& Komalasari, A., 2019, 'Effect of mandatory adoption of International financial reporting standard (IFRS) on supply chain management: A case of Indonesian dairy industry', Uncertain Supply Chain Management 7(2), 169-178. https://doi.org/10.5267/j.uscm.2018.10.008

Tshamaano, V., 2012, 'Impact of supply chain management on service delivery: The case of Provincial Department of Economic, Development, Environment and Tourism in the Limpopo Province, pp. 1-81, Masters, University of Limpopo.
Vanichchinchai, A. \& Igel, B., 2009, 'Total quality management and supply chain management: Similarities and differences', The TQM Journal 21(3), 249-260. https://doi.org/10.1108/17542730910953022

Wagner, C., Sancho-Esper, F. \& Rodriguez-Sanchez, C., 2020, 'Skill and knowledge requirements of entry-level logistics and supply chain management professionals: A comparative study of Ireland and Spain', Journal of Education for Business 95(1) 23-36. https://doi.org/10.1080/08832323.2019.1596870

Yang, Y., 2009, 'An investigation of group interaction functioning stimulated by transformational leadership on employee intrinsic and extrinsic job satisfaction: An extension of resource based theory perspective, Social behaviour and personality', An International Journal 37(9), 1259-1278. https://doi.org/10.2224/ sbp.2009.37.9.1259 